\title{
Analisa Citra Medis Pada Pasien Stroke dengan Metoda Peregangan Kontras Berbasis ImageJ
}

\author{
Budiani Destyningtias ${ }^{1)}$, Andi Kurniawan Nugroho ${ }^{2)}$, Sri Heranurweni ${ }^{3)}$ \\ Jurusan Teknik Elektro Universitas Semarang \\ Email : destyningtias@usm.ac.id, andikn@usm.ac.id, heranur@usm.ac.id
}

\begin{abstract}
Abstrak - Penelitian ini bertujuan mengembangankan teknologi pengolahan citra medis terutama citra medis CT Scan penderita stroke. Dokter dalam menentukan tingkat keparahan pasien stroke biasanya menggunakan citra medis CT scan dan mengalami kesulitan dalam menginterpretasikan luasan cakupan perdarahan.Solusi yang digunakan dengan peregangan kontras yang akan membedakan jaringan sel, tulang tengkorak dan jenis perdarahan. Penelitian ini menggunakan peregangan kontras dari hasil citra CT Scan yang dihasilkan dengan terlebih dahulu mengubah Citra DICOM menjadi citra JPEG dengan menggunakan bantuan program ImageJ. Hasil penelitian menunjukkan bahwa metode histogram ekualisasi dan analisis tekstur statistik dapat digunakan untuk membedakan yang normal MRI dan abnormal MRI yang terdeteksi stroke.
\end{abstract}

Kata - Kata Kunci : Stroke, MRI, Dicom, JPEG, ImageJ, Peregangan Kontras

\section{Pendahuluan}

Di berbagai negara maju penyakit degeneratif, seperti stroke, jantung, gagal ginjal dan lain-lain menjadi penyebab utama kematian. Stroke adalah salah satu penyakit yang memiliki jangka panjang yang menyakitkan. Efek dari serangan stroke dapat membuat orang hanya bisa berbaring di tempat tidur saja, bahkan untuk berbicara dengan jelas pun sangat sulit. Penyakit stroke dikenal dengan(Transient Ischemic Attacks atau TIA, Reversible Ischemic Neurological Deficit atau RIND dan Stroke) merupakan istilah umum bagi gangguan fungsi otak akibat terjadi kegagalan sirkulasi daerah di otak yang disebabkan gangguan pembuluh darah ke atau di otak. Salah satu cara untuk mendeteksi dini penyakit ini adalah dengan melakukan pemeriksaan, mengetahui dengan benar cara pencegahan terhadap penyakit diantaranya menerapkan perilaku hidup sehat dan rutin berolahraga. Sementara di Indonesia berdasarkan data dari tahun 1991 hingga tahun 2007 (hasil Riset Kesehatan tahun 2007) menunjukkan bahwa stroke merupakan penyebab kematian dan kecacatan utama di hampir seluruh Rumah Sakit di Indonesia. Sementara data Perhimpunan Rumah Sakit Indonesia (PERSI) tahun 2009 menunjukkan, penyebab kematian utama di RS akibat stroke adalah sebesar $15 \%$. Artinya 1 dari 7 kematian disebabkan oleh stroke dengan tingkat kecacatan mencapai 65 persen. Peningkatan prevalensi kasus stroke ini menunjukkan adanya ancaman serius bagi bangsa Indonesia.

Karena selain mengakibatkan menurunnya kualitas hidup penderitanya, stroke juga mengakibatkan beban sosial dan ekonomi bagi penderita dan keluarganya, masyarakat dan Negara.

Menurut Nurhayati (2008), salah satu pemeriksaan yang dapat digunakan untuk deteksi dini penyakit stroke adalah dengan $C T$ Scan. Namun citra yang diperoleh dari hasil $C T$ Scan memiliki kekurangan karena pada umumnya citra medis hasil scanning, yang berupa citra digital aras keabuan mengalami penurunan kualitas (terdegradasi) yang disebabkan faktorfaktor luar (derau) dan peralatan medis yang digunakan. Dengan demikian diperlukan proses pengolahan dengan peningkatan kualitas citra yang bertujuan untuk menghasilkan citra yang lebih baik dibandingkan dengan citra $C T$ Scan semula. Langkah selanjutnya yang diperlukan dalam pengolahan citra adalah segmentasi dengan membagi daerah citra berdasarkan kemiripan intensitas piksel (Leggett, 2004). Langkah selanjutnya adalah analisis citra yang menurut Munir (2004) bertujuan untuk mengidentifikasi dan menampilkan parameter-parameter yang diasosiasikan dengan ciri-ciri pada representasi objek didalam citra, untuk selanjutnya parameter tersebut digunakan sebagai interpretasi citra.

Di bidang kedokteran menurut (Nurhayati, 2008) citra medis pada umumnya mempunyai histogram yang cenderung berada di sekitar dark nilai pada aras keabuan sehingga pemanfaatan pengolahan citra digital dirasakan belum optimal, padahal dengan menggunakan utilitas ini dapat membantu para profesional radiolog dalam menentukan diagnostik suatu kelainan akibat kerusakan jaringan. Oleh karena itu, proses identifikasi kualitas citra MRI mutlak diperlukan untuk membantu tenaga medis dalam membaca hasil. Proses identifikasi dapat dilakukan dengan cara melakukan prapengolahan dan analisis citra. Salah satu bidang ilmu yang dapat melakukan analisis tersebut adalah bidang pengolahan citra. Beberapa penelitian mengenai pengolahan citra seperti yang telah dilakukan oleh Hariyadie (1995), Isnanto (2002), Legget (2004), Yulianto (2005), Tibyani (2005), Selecthi (2007), dan Nurhayati, dkk (2008), menunjukkan bahwa pengolahan citra dapat digunakan untuk meningkatkan kualitas citra dan diaplikasikan untuk menganalisis dan mengidentifikasi citra medis.

Penelitian ini penting dilakukan karena hasil MRI yang dibaca dengan benar dapat digunakan sebagai sarana deteksi dini terhadap penyakit stroke, serta memberikan kemudahan bagi tenaga medis dalam membaca hasil MRI sehingga kesalahan diagnosis secara minimal dapat dihindari. Penelitian ini dilakukan dengan beberapa kegiatan utama, yaitu: pada tahap awal penelitian akan dilakukan proses pengujian algoritma pra- pengolahan citra dengan metode kontras dan cerah serta filtering. Selanjutnya dilakukan analisis tekstur citra menggunakan bantuan software ImageJ.

\section{Tinjauan Pustaka}

Sejak ditemukan pemayar Computer Tomography Scanner (CT Scan) oleh Allan Cormack dan Geoffrey Hounsfiled pada tahun 1970, penggunaan $C T$ Scan dalam bidang radiologi telah mengalami kemajuan yang sangat pesat. Asal mula teknik ini digunakan untuk pemeriksaan otak, suatu tabung sinar-X 
tergandeng dengan dua detektor memanyar dua potongan yang berdekatan dari kepala dengan gerakan translasi. Dampak dari penggunaan sinar-X adalah menghitamkan film negatif. Oleh karena itu, benda-benda yang menyerap sinar lebih banyak (lebih rapat) akan ditampilkan dalam film negatif dengan warna yang lebih terang daripada benda-benda yang menyerap sinar lebih sedikit.

Jenis-jenis pemeriksaan radiologik di rumah sakit yang menggunakan peralatan $C T$ Scan dan dijumpai dalam praktik sehari-hari adalah stroke, kelainan saraf otak, kanker otak.Sebuah citra CT Scan dapat diketahui kualitasnya melalui sebuah histogram. Menurut Munir (2004), Histogram citra adalah grafik yang menggambarkan penyebaran nilai-nilai intensitas piksel suatu citra atau bagian tertentu atas citra. Dari sebuah histogram dapat diketahui frekuensi kemunculan nisbi intensitas pada citra tersebut. dengan histogramnya. Misalkan citra digital memiliki L derajat keabuan, yaitu dari nilai 0 sampai L-1 (misalnya pada citra dengan kuantisasi derajat keabuan 8-bit, nilai derajat keabuan dari 0 sampai 255).



Gambar 1. contoh citra digital CT Scan

Secara matematis histogram citra dihitung dengan persamaan (1) berikut.

$$
h i=\frac{n i}{n}, i=0,1, \ldots, L-1
$$

dengan

$\mathrm{ni}_{\mathrm{i}}=$ jumlah piksel yang memiliki derajat keabuan $\mathrm{i}$

$\mathrm{n}=$ jumlah seluruh piksel di dalam citra.

Distribusi $h_{i}$, atau $\mathrm{n}_{\mathrm{i}}$, dapat menyediakan informasi tentang kemunculan citra. Pengetahuan praktis untuk memahami histogram citra dibutuhkan untuk melihat perubahan-perubahan pada citra setelah dilakukan operasi tertentu. Beberapa pengetahuan praktis yang biasa digunakan dalam melihat histogram citra adalah sebagai berikut:

a. Histogram citra yang terdistribusi merata pada seluruh tingkat keabuan memiliki kontras yang baik.

b. Histogram citra yang mengumpul pada daerah gelap memiliki citra yang redup.

c. Histogram citra yang mengumpul pada daerah terang atau terkonsentrasi pada intensitas citra yang tinggi menampilkan citra yang terang.

Menurut Munir (2004), tujuan ekualisasi histogram adalah untuk memperoleh penyebaran histogram yang merata, sehingga setiap derajat keabuan memiliki jumlah piksel yang relatif sama.

\section{Metode Penelitian}

Bahan penelitian adalah citra DICOM MRI penderita stroke dan citra head MRI normal. Citra pasien stroke yang tersimpan dalam alat MRI masih dalam citra yang berekstensi DICOM. Dengan Menggunakan bantuan software ImageJ, citra yang berkentensi DICOM akan diubah menjadi citra yang berkentensi JPEG tanpa mengurangi nilai resolusi dari data asli dan akan memperbaiki citra yang tercampur dengtan noise yang dihasilkan dari proses pengambilan data

Data citra yang merupakan objek penelitian adalah citra otak sehat dan citra kelainan otak akibat stroke. Pada penelitian ini diambil potongan lapisan dari citra $M R I$ yang terdeteksi adanya kelainan otak. Ruang lingkup materi penelitian ini adalah pra- pengolahan citra dengan metode peregangan kontras dan analisis struktur perdarahan pasien penderita stroke.



Gambar 2. Diagram Blok Penelitian

\subsection{Perancangan Sistem}

\section{Hasil dan Analisa}

Berikut adalah perancangan flowchart dari aplikasi pengolahan citra untuk pengambilan data citra MRI pasien dalam ekstensi DICOM diubah ke dalam Ekstensi JPEG. 


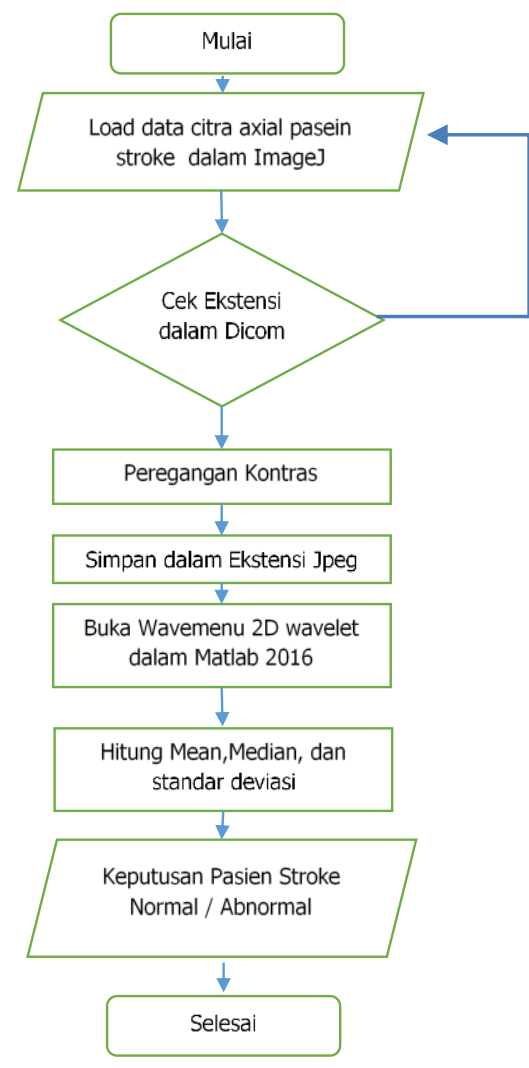

Gambar 3. Flowcart Analisa Citra Pasein Stroke

\subsection{Implementasi Sistem}

Penelitian ini menggunakan citra pasien stroke type perdarahan dengan pembanding pasien normal. Data pasien didapatkan dari data MRI dengan potongan secara axial karena bisa diamati luasan perdarahan.

\subsubsection{Loading Citra MRI dengan ImageJ}

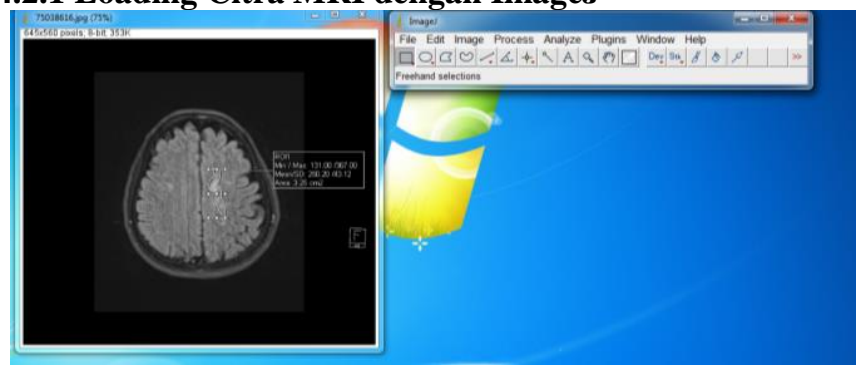

Gambar 4. Loading Citra MRI

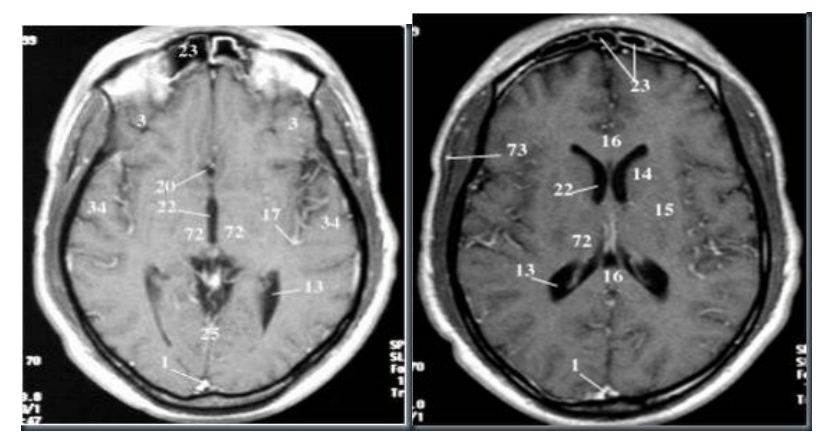

Keterangan gambar:

\begin{tabular}{|l|l|}
\hline 1. Sinus Sagital sup. & 44. Ventrikel IV \\
3. Lobus Frontal & 45. Cerebellum \\
4. Lobus Parietal & 48. Pons \\
13. Ventrikel Lateral & 50. Sinus Sphenoid \\
16. Corpus Callosum & 52. Medulla \\
17. A. Serebri Media & 55. Sinus Sigmoid \\
20. Foramen Monro & 63. Lidah \\
22. Ventrikel III & 67. Fornix \\
23. Sinus Frontal & 72. Thalamus \\
31. Aqueduct Serebri & 73. A. Meningeal \\
43. Arteri Basiler & \\
\hline
\end{tabular}

Pengambilan data citra MRI ( perdarahan di bagian Thalamus ) diambil salah satu potongan, kemudian dilakukan Region of Imaging ( ROI ) untuk membedakan daerah perdarahan atau tidak sehingga akan dihasilkan di bawah ini :

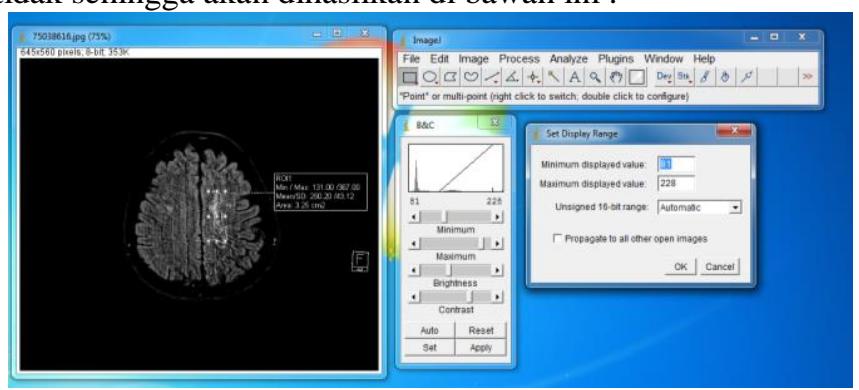

Gambar 6. Peregangan citra histogram dan ROI ( nilai peregangan 18, 228 )

Citra MRI yang telah dilakukan peregangan histogram, disimpan dalam bentuk JPEG untuk diolah dalam matlab.

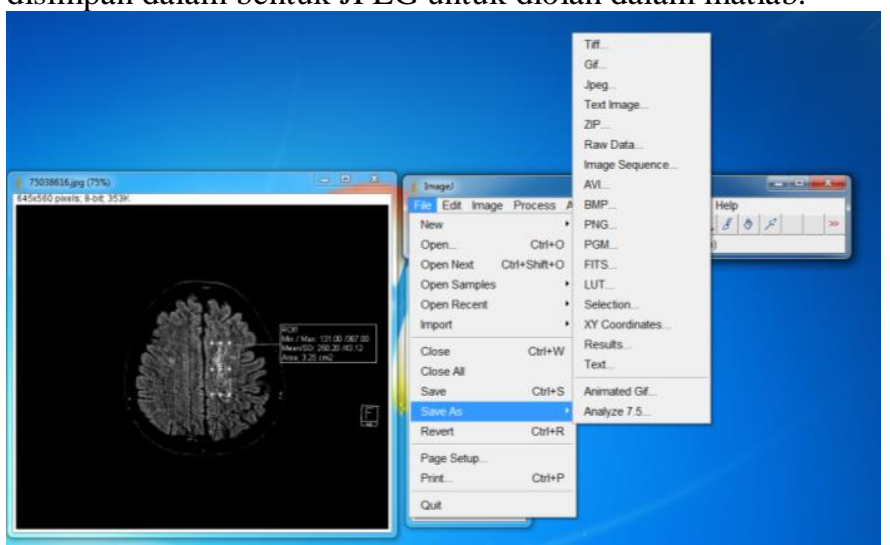

Gambar 7. Penyimpanan data MRI berekstensi DICOM ke JPEG

Gambar 5. Potongan Axial Otak MRI 


\subsubsection{Analisa Citra Menggunakan Matlab 2016}



Gambar 8. Analisa citra dengan matlab 2016

Untuk membedakan nilai histogram dari citra pasien stroke dengan normal, digunakan wavelet pada tool yang disediakan oleh Matlab 2016. Wavelet akan memberikan informasi citra digital dari MRI dengan analisa statistik citra digital.



Gambar 9. Analisa statistik histogram citra pasien stroke ( data pasien 1 )

Tabel 1. Data statistik citra digital pasien stroke

\begin{tabular}{|c|c|c|c|c|c|}
\hline No & $\begin{array}{c}\text { Nama } \\
\text { Pasien }\end{array}$ & Mean & Median & $\begin{array}{c}\text { Standar } \\
\text { Deviasi }\end{array}$ & $\begin{array}{c}\text { Kondisi } \\
\text { Pasien } \\
\text { Stroke }\end{array}$ \\
\hline 1 & Pasien1 & 25.91 & 16 & 38.56 & Perdarahan \\
\hline 2 & Pasien2 & 27.31 & 4 & 40.64 & Perdarahan \\
\hline 3 & Pasien3 & 28.87 & 11 & 40.89 & Perdarahan \\
\hline 4 & Pasien4 & 37.85 & 13 & 42.64 & Perdarahan \\
\hline 5 & Pasien5 & 20.03 & 0 & 38.39 & $\begin{array}{c}\text { Perdarahan } \\
\text { (Akut) }\end{array}$ \\
\hline 6 & Normal1 & 104.6 & 123.3 & 67.56 & Normal \\
\hline 7 & Normal2 & 80.97 & 92 & 60.48 & Normal \\
\hline 8 & Nprmal3 & 66.18 & 52 & 69.62 & Normal \\
\hline
\end{tabular}

\section{Kesimpulan}

1. Hasil analisis statistik dari fitur tekstur didapatkan bahwa citra digital head MRI yang terindikasi perdarahan memiliki nilai mean, standar deviasi, serta median yang paling kecil daripada citra digital Normal .

2. Nilai mean, standar deviasi, dan median paling kecil terdapat pada citra digital head MRI perdarahan akut.

3. Nilai standar deviasi citra head MRI normal memiliki nilai 60-70. Sedangkan nilai standar deviasi citra head MRI perdarahan 38-43.

\section{DAFTAR PUSTAKA}

Adib, Muhammad Cara Mudah Memahami dan Menghindari Hipertensi Jantung dan Stroke ( Yogyakarta, Dian Loka 2009)

Askep Pada Klien dengan Gangguan Sistem Persyarafan. 1996. Jakarta: Depkes Carpenito, 1995 Rencana Asuhan dan Dokumentasi Keperawatan. Jakarta:EGC

Gonzalez, R.C and Rafael E.W, 2008, Digital Image Processing, Prentice-Hall, Inc., United State, America.

Hariyadie, E., 1995, Deteksi Sisi Citra Tomografi, Skripsi Fakultas MIPA, Universitas Gadjah Mada, Yogayakarta.

Isnanto, R.R, 2002, Identifikasi Kerusakan Tulang Menggunakan Analisis Citra Foto Sinar-X, Tesis Teknik Elektro, Universitas Gadjah Mada, Yogyakarta.

Kapitaselekta Kedokteran. 1982. Jakarta: Media Aeskulapius FKUI

Leggett, R., 2004, Automatic Segmentation of Medical Images, http://www.google.com/dissertation.pdf.

Munir, R.,2004, Pengolahan Citra Digital dengan Pendekatan Logaritmik, Informatika, Bandung.

Nurhayati, O.D., A.Susanto, 2008, The Application of A Proper Segmentation Method in The Analysis of Head CT-Scan Images, International Joint Symposium Frontier in Biomedical Sciences: From Genes to Applications, UGM Yogyakarta

Paniran, 2001, Peningkatan Citra Medis Menggunakan Tapis Morfologi, Tesis S2 Program Studi Teknik Elektro, Universitas Gadjah Mada, Yogyakarta.

Seletchi, E.D., O.G.Duliu, 2007, Image Processing and Data Analysis in Computed Tomography, Rom.Journal of Phys,Vol.52, No.5-7,P.667-675, Bucharest

http://franzsinatrayoga.blogspot.co.id/2012/04/modul-pribadikoass-radiologi-istilah.html 